Copyright (C) 2015 by Academic Publishing House Researcher

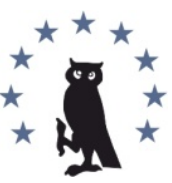

Published in the Russian Federation

European Researcher

Has been issued since 2010.

ISSN 2219-8229

E-ISSN 2224-0136

Vol. 98, Is. 9, pp. 578-589, 2015

DOI: $10.13187 / \mathrm{er} .2015 .98 .578$

www.erjournal.ru

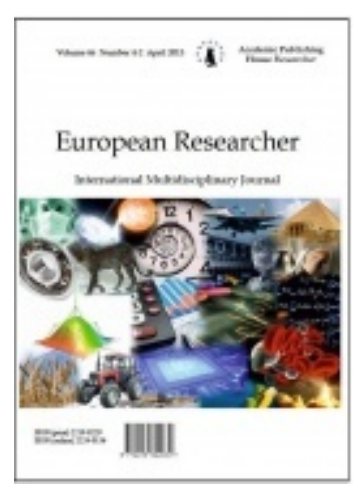

Economic sciences

Экономические науки

UDC 33

\title{
Tourist Valorization of the Mileševa Monastery (Serbia)
}

\author{
${ }^{1} \mathrm{~J}$ ovana Boškov \\ ${ }^{1}$ Stefan Kotrla \\ ${ }^{2}$ Kristina Košić \\ ${ }^{1}$ Dajana Lulić
}

${ }^{1}$ University of Novi Sad, Serbia

Faculty of Science, Department of Geography, Tourism and Hotel Management

Trg Dositeja Obradovića 3, 21 ooo Novi Sad

E-mail: boskovjovana@gmail.com

2 University of Novi Sad, Serbia

Faculty of Science, Department of Geography, Tourism and Hotel Management

Trg Dositeja Obradovića 3, 21 ooo Novi Sad

Associate Professor

\section{Abstract}

Mileševa monastery is located in the valley of Mileševka river, i.e. at the mouth of Kosanićka river in Mileševka river. It is six kilometers far from Prijepolje, and it is a seat of Mileševa Eparchy. The monastery was built in the style of Raška school, and dates from the period between 1219 and 1235. Mileševa monastery is of great importance for culture, art and history of Serbian people. It also plays an important role in tourism of Prijepolje and represents a cultural asset by which whole this place is largely known.

In this paper authors will present tourist valorization of the Mileševa monastery. The main objective of this paper is to evaluate the different values of this cultural asset using Hillary du Cros model of tourist valorization. Serbia

Keywords: tourist valorization, Hillary du Cros model, Mileševa monastery, Prijepolje,

\section{Introduction}

Achievements of Serbian culture, created for centuries, today play a major role in tourism development of this country. Among many cultural assets in Serbia, one of the most important are monasteries, whose emergence is closely related to the development of Serbian state. Formed mainly in medieval epoch, by time they grew into a national centers of education and culture. Serbian monasteries are the most beautiful works of architecture, painting and applied art, and it can be said that they are an important part of the European cultural heritage. This is confirmed by 
the fact that a large number of Serbian monasteries are declared as cultural monuments, and several of them are entered into the UNESCO list of world cultural heritage.

One of the monasteries, that has great significance for the culture and history of Serbian people is Mileševa. This medieval Serbian monastery, dedicated to the Ascension of Christ, is located near Prijepolje. It was built in the style of Raška school, and dates from the period between 1219 and 1235. It is known because the relics of Saint Sava were placed there, and still part of the hand of the first Serbian educator is kept in this monastery. In Mileševa monastery, in the 16th century, one of the first Serbian printing officies was working. Since 2011 the monastery became recognizable by the largest bell in Serbia, whose weight is nine tons. Fresco "The Marys at the tomb of Christ," more known as the "White Angel" represents an outstanding value of this monastery. Mileševa monastery, as well as many other Serbian monasteries, is a cultural asset that deserves a lot of attention in tourism valorization. This cultural asset has outstanding potential in tourism of Serbia. However, before any planning, a fundamental assessment of the condition and values of these objects is necessary. It can be achieved by proper tourist valorization.

"Tourist valorization presents a detailed assessment of natural and man-made values of importance to the development of tourism at one site, in one center, one place, geographical region or in country as a whole" (Stanković, 2004). It is necessary to accentuate that the reliability of tourist valorization is limited, because the assessment is based on subjective perception and evaluation of assessors. The needs and interests of visitors are very important during the valorization of tourist objects. The inclusion of visitors into evaluation process is a good way to achieve objectivity (Tomić, 2011).

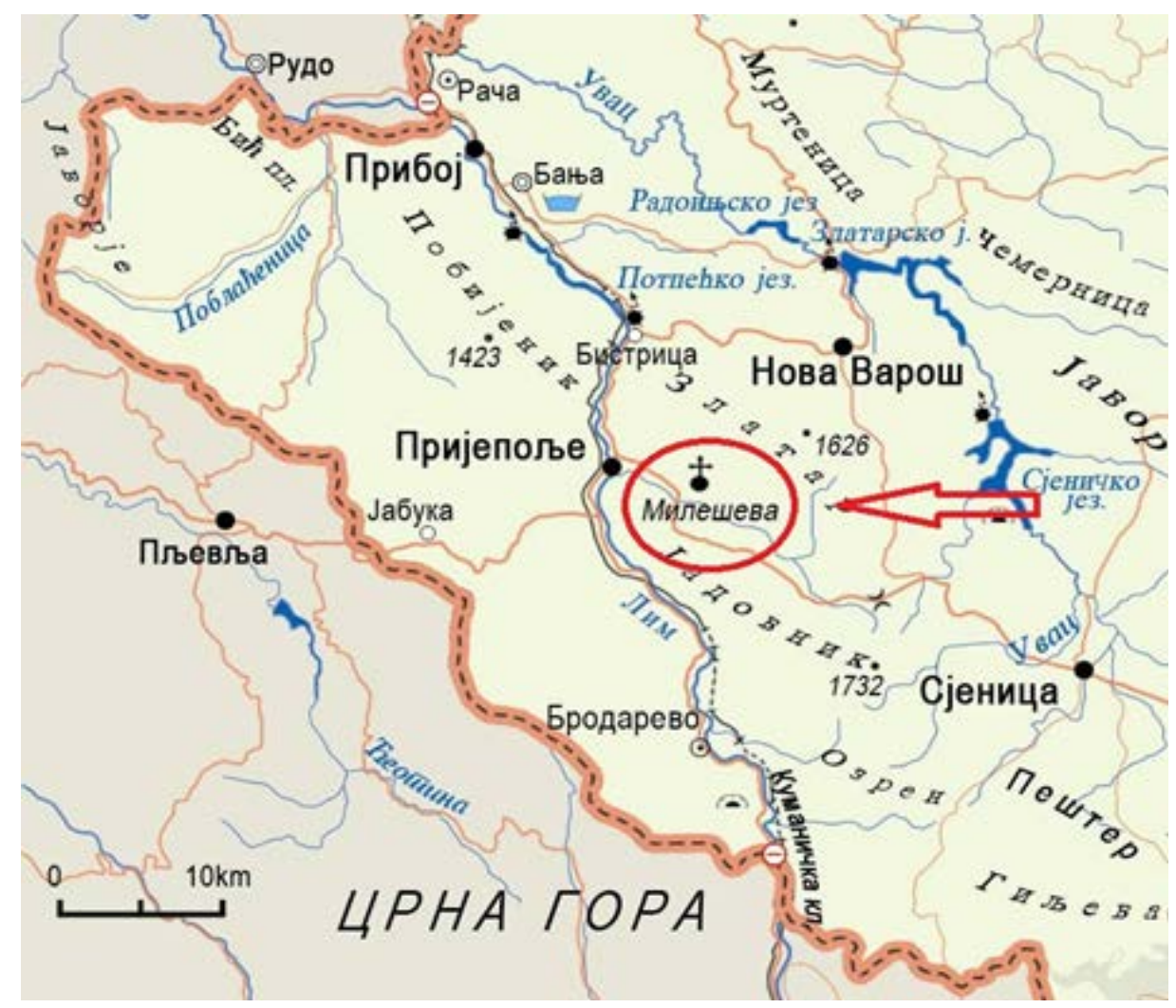

Figure 1. Geographic location of Mileševa monastery within the Prijepolje municipality Source: Drobnjaković, 2012

\section{Geographical position of Prijepolje and Mileševa monastery}

Prijepolje area is a border zone in the Republic of Serbia. It is formed at the crossroads of three countries of former Republic of Yugoslavia (Serbia, Montenegro and Bosnia and Herzegovin.a). To the south it borders with Montenegro (municipalities of Pljevlja and .Bijelo Polje), to the west it borders with Srpska Republic (municipalities Rudo and Čajniče), while on the 
other sides it is bordered by the municipalities in Serbia (to the north by the municipalities of Čajetina and Arilje, to the east by the municipality of Ivanjica and to the southeast by the municipality of Sjenica). According to geographical regional division it is located in Starovlaška region, in the subregion of middle and lower Polimlje. According to administrative-territorial division it belongs to the Zlatibor district. The whole territory has distinctly mountainous character. This has historically been an important transit area, because it was located at the crossroads of the old Roman roads, then Bosnian and Dubrovnik road, which served as the basis for development of today's road network (Drobnjaković, 2012).

Geographical position of Prijepolje is very favorable because it is located on important traffic routes. Across the main road E-763 (Beograd-Čačak-Zlatibor-Podgorica) Prijepolje is connected to one of the 10 major European corridors, the corridor 10 (i.e. with highways E-70 and E-75). Prijepolje is also connected to Corridor 10 across the road E-76 (Čačak/Preljina-Kraljevo-KruševacPojate), which continues to the already mentioned road E-763 (Plavša and Ratković, 2007).

Mileševa monastery is located at the mouth of the Kosanićka river in Mileševka river. It is six kilometers far from Prijepolje, and it is a seat of Mileševa Eparchy.

\section{History of the monastery}

Monastery Mileševa was raised by the Serbian King Vladislav, as his mausoleum. It was built in the style of Raška School. Time of construction of the Mileševa monastery is not accurately determined. According to some sources, the construction began at a time when Vladislav was not yet crowned, while according to other sources Vladislav began to erect the monastery immediately after his accession to the throne, that is after the year 1234. Nevertheless, if taken into consideration both historical facts and testimonies on frescos, construction and painting of Mileševa can be placed in the years between 1219 and 1235 (Janković, 2007; Mandić, 2012). In the period around year 1235 King Vladislav built one more narthex, to bury the body of his uncle, the first Serbian Archbishop Sava in it. In 1236, Vladislav moved the relics of his uncle Saint Sava from Trnovo in Bulgaria, where he died, to Mileševa. In 1595 the Turks took the bones to Belgrade and burnt them in Vračar.

In this monastery in 1377, Tvrtko Kotromanić was crowned as king of Bosnia and Serbia. The Turks destroyed Mileševa for the first time in 1459. However, ecclesiastical and educational life went on, with only occasional discontinuities. After the 1594, when Turks took the body of St. Sava to Belgrade and burned it, Mileševa monastery become poor. There are numerous data that monks from Mileševa went to Wallachia and Russia to collect donations for the monastery. In the 16th and 17th centuries many prominent travelers visited the monastery and sometimes they found it crowded and well-being, but sometimes they were witnesses of its troubles. In the 17th century significant repairs of the monastery buildings were made. At the end of this century, the Turks burned konaks and looted the monastery. Monks transferred some of the valuables to Austria. Often abandoned, the monastery was increasingly decaying. In 1857, famous Russian traveler and scientist Giljferding found the church in ruins. He writes that the whole church is in ruins, the walls and roofs are gone, the dome are almost completely destroyed and are adhered only to parts of the vaults. Later, in 1863, the church was restored through the efforts of citizens of Prijepolje. During this reconstruction collapsed roofs and dome were erected, a semicircular apse was built, so the monastery got its present external look.

During the Second World War, occupying forces of Germany and Italy were imprisoning horses and mules in the monastery. On that occasion, because of the layers of garbage and ammonia, frescoes of Mileševa were heavily damaged (Mandić, 2012). 


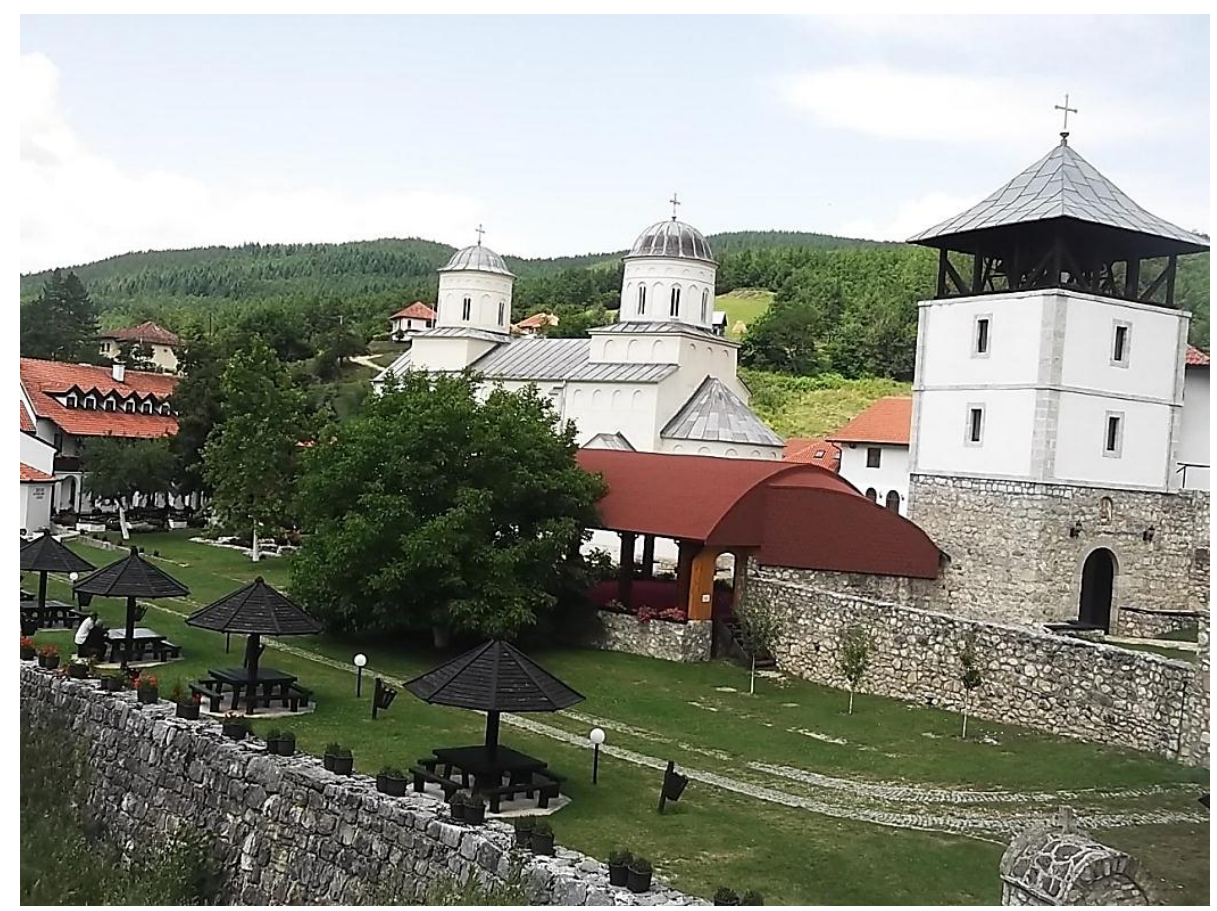

Figure 2. Complex of Mileševa monastery

(Photo by: J . Boškov, 2013)

In the early 20th century in this monastery extensive works were carried out. The pond and new economy are built, large konak, smaller konak and steeple are renovated etc. In 2008 the Radio "Mileševa", located within the monastery complex, was founded. A year later, the monastery treasury was built (Mandić, 2012).

\section{Methodology}

Tourist valorization is one of the most important phases in the process of spatial planning of tourism. It represents the establishment of tourist evaluation or appraisal of tourist attraction, i.e. evaluation of tourist attractions and assessment of any phenomena, objects and spaces that have, among other characteristics, a feature that are attractive (interesting) for tourists, and through them tourists can meet their (cultural or recreational) needs (Tomka, 1998).

There is a large number of different models of tourist valorization. One of them is Hillary du Cros model, that is used for the evaluation of cultural assets. Du Cros (2000) in the process of tourist valorization introduces cultural-tourism sub-indicators and the level of their grading, separately for the tourism sector and separately for the sector of cultural assets management (Hadžić, 2005). In tourism sector, the market attractiveness of cultural assets and factors important for the design of a tourist product are evaluated. In sector of management of cultural assets, two element are being evaluated: cultural significance and robustness. Each sub-indicator is separately evaluated with grades from 0 to 5, the highest individual grade for some subindicators can be less than 5, then the grades summarize and provide a summary evaluation for each sector. The maximum number of points for each group of sub-indicators (tourism sector and sector of management of cultural assets) is 60.

Based on the evaluation score, a matrix of "market attractivness/robustness" with 9 cells is set. The cells are marked with $M(i, j)(i, j=1,2,3)$ and each cultural asset occupies one cell in the matrix, depending on the score given in the previous assessment process (Hadžić, 2005; Besermenji and Pivac, 2008).

The cells are defined as following (Du Cros 2000):

- M $(1,1)$ - high value of indicators of cultural importance/robustness and low market attractiveness,

- M $(1,2)$ - high value of indicators of cultural importance/robustness and medium market attractiveness, 
- M $(1,3)$ - high value of indicators of cultural importance/robustness and high market attractiveness,

- M $(2,1)$ - medium value of indicators of cultural importance/robustness and low market attractiveness,

- $M(2,2)$ - medium value of indicators of cultural importance/robustness and medium market attractiveness,

- M $(2,3)$ - medium value of indicators of cultural importance/robustness and high market attractiveness,

- M (3,1) - low value of indicators of cultural importance/robustness and low market attractiveness,

- M $(3,2)$ - low value of indicators of cultural importance/ robustness and medium market attractiveness,

- M (3,3) - low value of indicators of cultural importance/robustness and high market attractiveness.

\section{Tourist valorization of the Mileševa monastery using Hilary du Cros model}

In order to avoid subjectivity, in the process of tourist valorization in this study 10 tourists were included. When choosing a sample, it was taken into account that all the respondents are familiar to the site and that they visited the monastery at least once in the last three years. Based on their answers and evaluation of all sub-indicators, average grades of each sub-indicator of tourist value are given, thus a certain objectivity in the assessment of the tourist attractions of this cultural good is achieved.

\section{Market attractivness of cultural asset}

The ambience (weak 0-1, adequate 2-3, good 4, great 5) - Mileševa monastery is situated in a quiet valley, five kilometers upstream from the mouth of the rivers Mileševka and Lim. The preserved nature in the vicinity of the monastery, as well as well tended interior within the complex (benches, paths, flowers) provide a nice atmosphere. However, the ambience can be improved so the grade is 4 .

Site is well known outside the local area (not 0-1, to some extent 2-3, very well 4-5) - the monastery is well known not only in the local area but also at the national level. A picture of the White Angel of Mileševa was sent as a message in the first satellite broadcast signal from Europe to America, as a symbol of peace and civilization. Later, the same signal, containing the White Angel, was transmitted to space in an attempt to communicate with extraterrestrial life forms. It can be said that this cultural asset is known internationally. The grade is 5.

An important national symbol (not 0, has a potential 1-3, yes 4-5) - Mileševa monastery is a symbol of Prijepolje and certainly one of the symbols of medieval Serbia. The assessment of its significance as a national symbol is 4 , due to the existence of other similar monasteries in the Republic of Serbia.

Interesting story could be told - evocative place (not 0 , has a potential 1-3, yes 4-5) - there are numerous historical facts and stories about this cultural asset (such as story about Kalistrat and Cassian). The grade is 4.

Site is different from other nearby cultural assets (poor 0, adequate 2-3, good 4, 5 excellent) - despite some unique elements, a grade for differentiation of monastery complex is 3 , due to the existence of numerous monasteries and cultural resources in the environment, also dating from the period of medieval Serbia (monasteries Davidovica, Mili, Kumanica, medieval fortresses Mileševac and Kovin, etc).

Attractiveness for special purposes (not at all 0 , has a potential 1-3, very good 4-5) monastery has limited capabilities for special purposes. There is a possibility of organizing church conferences, religious celebrations, concerts. The grade is 2.

Complementary to other tourism products at the destination/ in the region (not at all 0 , has a potential 1-3, yes 4-5) - the monastery is characterized by a high degree of complementarity with other tourism products in the region, as well as with surrounding cultural assets. The existence of a large number of religious buildings, historic sites and monuments in the vicinity of the monastery favors the creation of a variety tours of cultural, religious, educational, and other forms of tourism. The grade is 5. 
Tourist activity in the region (almost none 0 , in some extent 2-3, high 4-5) - is relatively weak. It is promoted on the tourism fairs in the region, but the propaganda material of the monastery is present only in small extent. Within the monastery complex there is a gift shop. The monastery has its own radio program (Radio "Mileševa"). As disadvantage states that the monastery does not have a website. Grade for tourist activity is 2.

Cultural asset associates with culture (not at all 0, in some extent 2-3, high 4-5) - monastery largely reflects the culture, history and art of the Serbian people. Republic Institute for Protection of Cultural Monuments declared Mileševa as cultural heritage of exceptional importance. The grade is 5.

Factors important for design of a tourist product

The accessibility of site (not allowed 0 , limited 1-2, allowed access to all elements of the site 3-4) - from Prijepolje to the monastery leads a relatively good asphalt road. Within the complex, access to all the elements of cultural asset is highly present. The grade is 3.

Transportation from the population center to cultural asset (long distance/ difficult access 0 , enabled access 1-2, easy access 3) - although it is located in the southwest, provincial part of Serbia, municipality of Prijepolje has a favorable position towards the places from which tourists come (Plavša and Ratković, 2007). The nearest population center is Prijepolje, which is located about six kilometers far from the monastery. There is no organized transport from Prijepolje to the monastery. Until last year there was a tourist train, which is owned by the monastery, but for technical reasons it no longer drives travelers. Transportation is available by local taxis and school bus (data obtained from curator of the monastery). From all the population cities, the monastery can be easily reached by car. The grade is 2 .

Proximity of other cultural attractions (long distance/ difficult access 0 , enabled access 1-2, the distance can be easily crossed by foot 3) - in the vicinity of the monastery is a medieval fortress Mileševac, then the medieval fortress Kovin, archaeological site Dvorine. In Prijepolje, which is six kilometers far from the monastery, there are many other attractions such as the Clock Tower, mosques from the Ottoman period (most notably Hisardžik, Sinan Pasha's Mosque, Ibrahim Pasha's Mosque), the memorial park "4th December ", the Regional Museum and many others. The distance of these attractions from the monastery Mileševa not exceed 15 kilometers, and access is significantly facilitated by good transport links. The grade is 2 .

Service facilities (weak 0, adequate 1-2, good 3-4, excellent 5) - along the road to Prijepolje, as well as to some villages in the municipality of Prijepolje there are signposts indicating the monastery. There are no additional tables with an explanation of how to get to the monastery. In front of the complex there is a large parking area, as well as info table with removable and fixed contents. In the guest reception building there is refreshment that is free of charge (if they want, visitors can leave donations for the reconstruction of the monastery), in the gift shop is possible to get information from the monks, it is also possible to buy publications where you can find all the relevant information about the monastery, as well as other souvenirs. Within the monastery complex there are three dormitory for guests. Guests have access to rooms with balconies and a bathroom, with a total capacity of 186 beds. Rooms are single, double, triple, as well as with four and five beds. There are also lounges for relaxation and conversation, as well as summer houses near the temple (data obtained from curator of the monastery). Service facilities are at a high level, however they can still be improved so the grade is 4 .

Table 1. Estimated values of sub-indicators for the tourism sector

\section{TOURISM SECTOR}

- MARKET ATTRACTIVENESS -

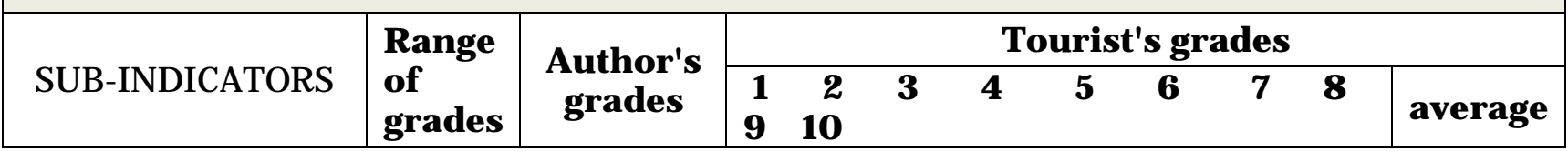




\begin{tabular}{|l|c|c|c|c|c|c|c|c|c|c|c|c|c|}
\hline Ambience & $0-5$ & 4 & 4 & 5 & 5 & 5 & 5 & 4 & 3 & 5 & 4 & 5 & 4,5 \\
\hline $\begin{array}{l}\text { Well known outside } \\
\text { the local area }\end{array}$ & $0-5$ & 5 & 5 & 5 & 3 & 4 & 5 & 5 & 5 & 4 & 4 & 5 & 4,5 \\
\hline $\begin{array}{l}\text { An important } \\
\text { national symbol }\end{array}$ & $0-5$ & 4 & 4 & 4 & 5 & 3 & 4 & 3 & 5 & 4 & 5 & 4 & 4,1 \\
\hline Evocative place & $0-5$ & 4 & 4 & 4 & 4 & 3 & 4 & 3 & 5 & 3 & 3 & 4 & 3,7 \\
\hline $\begin{array}{l}\text { Differentiation from } \\
\text { other nearby cultural } \\
\text { assets }\end{array}$ & $0-5$ & 3 & 5 & 4 & 4 & 5 & 5 & 4 & 5 & 4 & 4 & 4 & 4,4 \\
\hline $\begin{array}{l}\text { Attractiveness for } \\
\text { special purposes }\end{array}$ & $0-5$ & 2 & 2 & 2 & 2 & 0 & 1 & 3 & 1 & 2 & 2 & 3 & 1,8 \\
\hline $\begin{array}{l}\text { Complementary to } \\
\text { other tourism } \\
\text { resources }\end{array}$ & $0-5$ & 5 & 3 & 2 & 4 & 3 & 3 & 3 & 4 & 4 & 3 & 5 & 3,4 \\
\hline $\begin{array}{l}\text { Tourist activity in } \\
\text { the region }\end{array}$ & $0-5$ & 2 & 3 & 0 & 2 & 3 & 2 & 4 & 2 & 0 & 2 & 3 & 2,1 \\
\hline $\begin{array}{l}\text { Associated with } \\
\text { culture }\end{array}$ & $0-5$ & 5 & 5 & 4 & 3 & 5 & 5 & 4 & 2 & 5 & 4 & 5 & 4,2 \\
\hline
\end{tabular}

FACTORS IMPORTANT FOR DESIGN OF A TOURIST PRODUCT -

\begin{tabular}{|c|c|c|c|c|c|c|c|c|c|c|c|c|c|}
\hline \multirow[b]{2}{*}{ SUB-INDICATORS } & \multirow{2}{*}{$\begin{array}{l}\text { Range } \\
\text { of } \\
\text { grades }\end{array}$} & \multirow{2}{*}{$\begin{array}{l}\text { Author's } \\
\text { grades }\end{array}$} & \multicolumn{11}{|c|}{ Tourist's grades } \\
\hline & & & 9 & $\begin{array}{r}2 \\
10\end{array}$ & & & & 5 & 6 & 7 & & 8 & average \\
\hline Accessibility of site & $0-4$ & 3 & 4 & 2 & 2 & 4 & 4 & 4 & 2 & 3 & 4 & 4 & 3,3 \\
\hline $\begin{array}{l}\text { Transportation from } \\
\text { the population } \\
\text { center }\end{array}$ & $0-3$ & 2 & 2 & 2 & 2 & 0 & 3 & 3 & 2 & 2 & 2 & 2 & 2 \\
\hline $\begin{array}{l}\text { Proximity of other } \\
\text { cultural attractions }\end{array}$ & $0-3$ & 2 & 2 & 1 & 2 & 3 & 2 & 2 & 2 & 2 & 2 & 2 & 2 \\
\hline Service facilities & $0-5$ & 4 & 5 & 4 & 4 & 3 & 5 & 3 & 1 & 4 & 3 & 3 & 3,5 \\
\hline \multicolumn{2}{|l|}{ TOTAL GRADE } & 45 & & & & & & & & & & & 43,5 \\
\hline
\end{tabular}

Overall rating of sub-indicators of market attractiveness in the tourism sector by the authors is 45 , while the average grade by tourists is 43,5 which leads to the conclusion that the monastery Mileševa is characterized by a high level of market attractiveness (low attractiveness 0-20, medium attractiveness 21-40, high attractiveness 41-60).

Cultural significance

Aesthetic value (low 0, medium 1, high 2) - the entire monastery complex has a great aesthetic value. Built in the style of Raška school, it represents a unique synthesis of Byzantine and Romanic architecture, based on which gradually built up an original architectural-artistic style of construction in the medieval Serbian state (Dulić, 2001). At the beginning of the 21st century began the largest restoration in the history of the monastery. Large konak, smaller konak and steeple are renovated. The pond, new economy and watermill, as well as the monastery treasury and library were built (Mandić, 2012). In addition, the complex is very nicely decorated, with paths and benches. The grade for this sub-indicator is 2 .

Historical value (low 0, medium 1, high 2) - considering that the monastery kept the relics of St. Sava, which is one of the most important figures in Serbian history and culture, that in a monastery in the 16th century worked one of the first Serbian printing house, that he had suffered a number of Turkish attacks and destruction, and that the fresco White Angel of Mileševa via satellite transmission of video signal (1962) is shown in North America, it may be concluded that the historical value of the monastery is high, grade 2 . 
Educational value (low 0, medium 1, high 2) - old manuscripts and incunabula, such as Srbulj from old Serbian printing houses, numerous contemporary monographic books in different languages, then calendars, posters, sheet materials, postcards, photographs and tapes are kept in the library of the monastery. The setting of the monastery treasury consists of over 80 exhibits (Mandić, 2012). For this sub-indicator the grade is 2.

Social value (low 0 , medium 1 , high 2 ) - social value of the monastery is reflected in the fact that religious ceremonies are being held in it. Monastery represents an area where locals and many tourists are meeting. The grade is 1.

Scientific-research value (low 0 , medium 1 , high 2 ) - the monastery attracts the attention of researchers in a small scale. That are mostly priests and students of theology, who use the extensive library materials of the monastery library for their research. This sub-indicator received a grade 1.

Rarity of cultural asset at the destination/ in the region (usual cultural assets of same type 0, unusual cultural assets of same type 1, rare cultural assets of same type 2, unique cultural asset 3) - by its characteristics the monastery differ from the surrounding cultural assets, but not to a great extent. Throughout Serbia there are a number of medieval churches and monasteries, so the grade for this sub-indicator is 1.

Representativeness for destination (weak 1, good 2-3, great 4) - thanks to its historical, cultural and artistic significance, Mileševa monastery is very representative locality, that is attractive for tourist visits. Particularly noteworthy is the fresco White Angel, thanks to which the monastery, and this whole area became known beyond the borders of Serbia. The grade shall be 4 .

\section{Robustness}

Sensitivity of cultural asset (big 0, considerable 2-3, not sensitive 4) - if adhering to certain standards of behavior, the monastery complex is able to accept a large number of visitors, without prejudice to the physical condition. However, in order to prevent their damage, it is necessary to limit the access to some parts of the cultural asset. Above all, this refers to frescos and exhibits in the monastery treasury. The grade is 3.

Reparation condition (weak 0, partly repaired 1, good 2-3, great 4) - in the first years of the 21st century extensive works on the entire complex were carried out. Konaks and steeple are renovated, the pond, new economy, watermill, monastery treasury and library were built. Some improvements are still possible, so the grade is 3.

Existence of cultural asset management plan (not existing 0, in preparation 1-4, exists 5) - protection of the monastery is in charge of the Republic Institute for Protection of Cultural Monuments. However, cultural asset management plan does not exist, the grade is 0.

Regulatory monitoring and maintenance (0 weak, partly 1-2, good 3-4 , excellent 5) - There is no records of the number of visitors. The monastery complex has its own security. In cooperation with local police the security is taken into account. Within the complex there is one police officer at any time of day or night. Monitoring and maintenance are present, but not sufficiently, so the grade is 3.

Potential for ongoing investment and consultation of key stakeholders (weak 0, adequate 1-2, good 3-4, excellent 5) - the potential exists, but is minimally present. Investments are present by individuals, and refer to a voluntary contribution for the reconstruction of the monastery. The grade is 2.

Possibillity of negative impact of a large number of visitors to the physical condition of cultural asset (great possibility 1, medium possibility 2-4, small possibility 5) and the lifestyle and cultural traditions of the local community (great possibility 1, medium possibility 2-4, small possibility 5) - the assumption is that a large number of visitors, due to inadequate behavior could have a negative impact on the physical condition of cultural asset. The grade for this subindikator is 4. Given the fact that the monastery is located outside of settlements, influence to the lifestyle, culture and tradition of the local community is minimal. Short-term contact between tourists and locals from nearby places happens only during their visits to the cultural asset, and it's achieved without major impact. The grade is 5.

Possibility that modification, as part of product development, has a negative impact on the physical condition of cultural asset (great possibility 1, medium possibility 2-4, small possibility 5) and the lifestyle and cultural traditions of the local community (great possibility 1, medium possibility $2-4$, small possibility 5 ) - the possibillity of negative impact of modification to the 
physical condition of cultural asset exists, especially if modification would imply a change of the original appearance of the monastery. The grade is 4 . The possibillity of negative impact of modification to the local community is negligible because as already mentioned, the cultural asset is located outside the settlement. The grade for this sub-indicator is 5.

Table 2. Estimated values of sub-indicators for the sector of management of cultural asset

\section{SECTOR OF MANAGEMENT OF CULTURAL ASSET}

- CULTURAL SIGNIFICANCE -

\begin{tabular}{|c|c|c|c|c|c|c|c|c|c|c|c|c|c|}
\hline \multirow{2}{*}{ SUB-INDICATORS } & \multirow{2}{*}{$\begin{array}{l}\text { Range } \\
\text { of } \\
\text { grades }\end{array}$} & \multirow{2}{*}{$\begin{array}{l}\text { Author's } \\
\text { grades }\end{array}$} & \multicolumn{11}{|c|}{ Tourist's grades } \\
\hline & & & $\mathbf{1}$ & 2 & 3 & 4 & 5 & 6 & 7 & 8 & 9 & 10 & average \\
\hline Aesthetic value & $0-2$ & 2 & 2 & 2 & 2 & 2 & 2 & 1 & 2 & 2 & 2 & 2 & 1,9 \\
\hline Historical value & $0-2$ & 2 & 2 & 2 & 2 & 2 & 2 & 2 & 2 & 2 & 2 & 2 & 2 \\
\hline Educational value & $0-2$ & 2 & 2 & 2 & 2 & 2 & 1 & 1 & 2 & 2 & 2 & 2 & 1,8 \\
\hline Social value & $0-2$ & 1 & 2 & 1 & 2 & 2 & 2 & 1 & 2 & 2 & 2 & 2 & 1,8 \\
\hline $\begin{array}{l}\text { Scientific-research } \\
\text { value }\end{array}$ & $0-2$ & 1 & 2 & 1 & 2 & 1 & 1 & 0 & 1 & 1 & 1 & 2 & 1,2 \\
\hline $\begin{array}{l}\text { Rarity of cultural } \\
\text { asset at the } \\
\text { destination/in the } \\
\text { region }\end{array}$ & $0-3$ & 1 & 2 & 2 & 2 & 2 & 3 & 2 & 3 & 3 & 0 & 1 & 2 \\
\hline $\begin{array}{l}\text { Representativeness } \\
\text { for destination }\end{array}$ & $0-4$ & 4 & 4 & 3 & 4 & 4 & 4 & 3 & 3 & 3 & 3 & 3 & 3,4 \\
\hline \multicolumn{14}{|c|}{ - ROBUSTNESS - } \\
\hline \multirow{2}{*}{ SUB-INDICATORS } & \multirow{2}{*}{$\begin{array}{l}\text { Range } \\
\text { of } \\
\text { grades }\end{array}$} & \multirow{2}{*}{$\begin{array}{l}\text { Author's } \\
\text { grades }\end{array}$} & \multicolumn{11}{|c|}{ Tourist's grades } \\
\hline & & & 1 & 2 & 3 & 4 & 5 & 6 & 7 & 8 & 9 & 10 & average \\
\hline $\begin{array}{l}\text { Sensitivity of cultural } \\
\text { asset }\end{array}$ & $0-4$ & 3 & 4 & 4 & 3 & 3 & 3 & 4 & 0 & 3 & 3 & 3 & 3 \\
\hline Reparation condition & $0-4$ & 3 & 4 & 2 & 2 & 2 & 4 & 2 & 1 & 3 & 3 & 4 & 2,7 \\
\hline $\begin{array}{l}\text { The existence of a } \\
\text { cultural asset } \\
\text { management plan }\end{array}$ & $0-5$ & 0 & 5 & 1 & 1 & 0 & 0 & 3 & 1 & 3 & 3 & 0 & 1,7 \\
\hline $\begin{array}{l}\text { Regulatory } \\
\text { monitoring and } \\
\text { maintenance }\end{array}$ & $0-5$ & 3 & 5 & 3 & 2 & 4 & 5 & 3 & 1 & 4 & 2 & 4 & 3,3 \\
\hline $\begin{array}{l}\text { The potential for } \\
\text { ongoing investment }\end{array}$ & $0-5$ & 2 & 4 & 3 & 5 & 4 & 4 & 2 & 3 & 3 & 2 & 4 & 3,4 \\
\hline $\begin{array}{l}\text { Negative impact of a } \\
\text { large number of } \\
\text { visitors to the } \\
\text { physical condition }\end{array}$ & $0-5$ & 4 & 3 & 3 & 3 & 5 & 3 & 4 & 1 & 3 & 2 & 5 & 3,2 \\
\hline $\begin{array}{l}\text { Negative impact of a } \\
\text { large number of } \\
\text { visitors to the lifestyle }\end{array}$ & $0-5$ & 5 & 5 & 5 & 5 & 2 & 5 & 4 & 2 & 3 & 3 & 3 & 3,7 \\
\hline $\begin{array}{l}\text { Negative impact of } \\
\text { modific. to the } \\
\text { physical condition }\end{array}$ & $0-5$ & 4 & 3 & 2 & 5 & 4 & 3 & 3 & 1 & 3 & 3 & 2 & 2,9 \\
\hline
\end{tabular}




\begin{tabular}{|l|c|c|c|c|c|c|c|c|c|c|c|c|c|}
\hline $\begin{array}{l}\text { Negative impact of } \\
\text { modification to the } \\
\text { lifestyle }\end{array}$ & $0-5$ & 5 & 3 & 5 & 3 & 5 & 5 & 3 & 2 & 3 & 3 & 3 & 3,5 \\
\hline TOTAL GRADE & $\mathbf{4 2}$ & $\mathbf{4 1 , 5}$ \\
\hline
\end{tabular}

Overall rating of sub-indicators for the sector of management of cultural assets by the authors is 42. This group of sub-indicators tourists have evaluated with grade 41.5 which represents a high value (low sensitivity/cultural value 0-20, medium value 21-40, high value 41-60).

Based on the previous rating in the process of tourist valorization, cultural asset is placed in a proper field of the matrix.

Table 3. Classification of cultural asset in a certain field of matrix

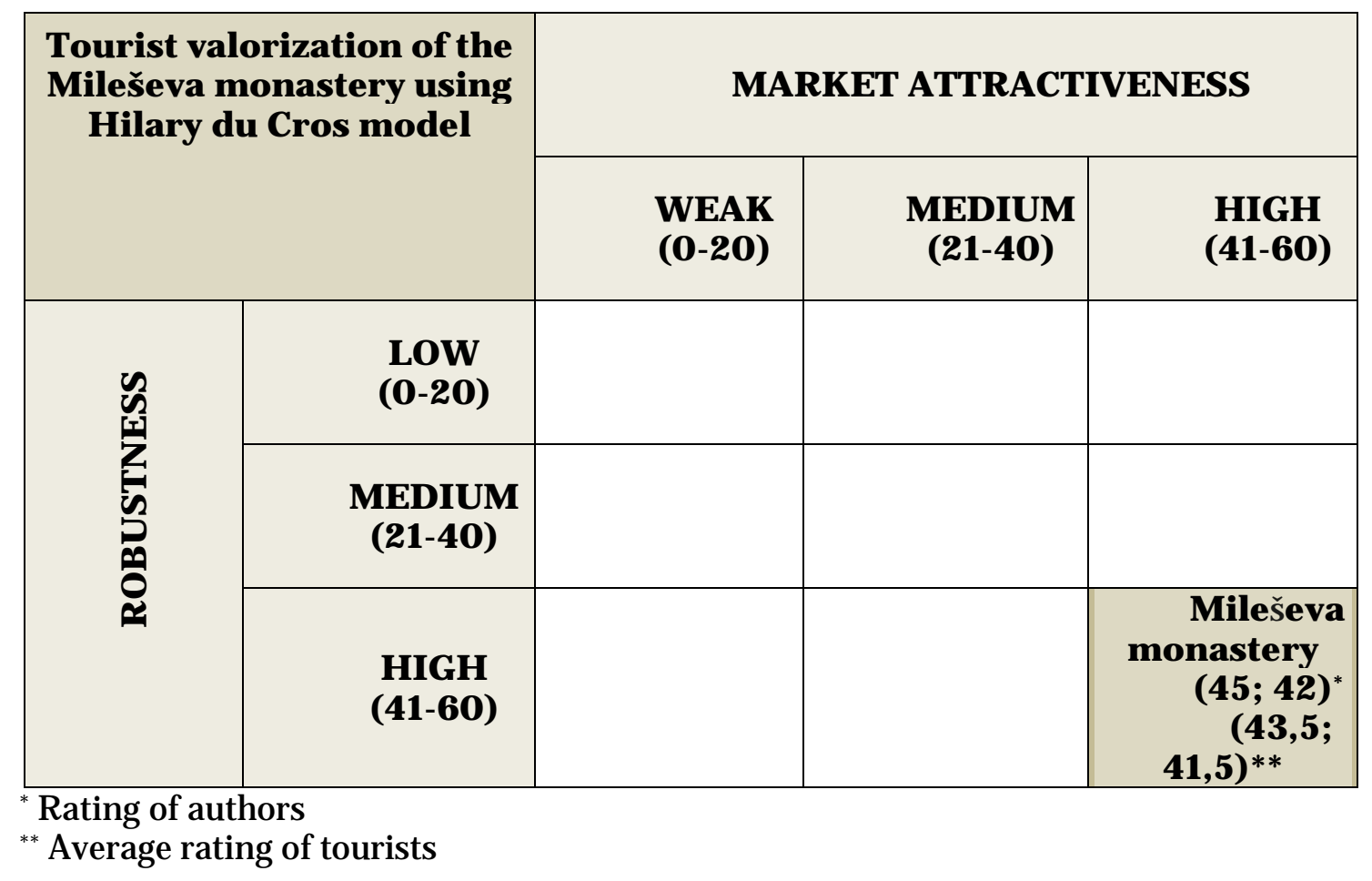

As can be seen from Table 3, the monastery Mileševa is characterized by high value of market attractiveness for the tourism sector, as well as the high value of robustness. The process of tourist valorization leads to the conclusion that this cultural asset is suitable for tourist visits, which is confirmed by high level of agreement in the estimation of the authors and tourists.

\section{Conclusion}

Comparing the grades given by authors and by tourists a high degree of congruence is evident. Overall rating for a group of sub-indicators within the tourism sector by authors is 45 , while the average grade by tourists is 43,5 , so in the opinion of both, the monastery Mileševa is characterized by high value of market attractiveness for the tourism sector. Within this group of sub-indicators, the most noticeable deviation in the evaluation of tourists and author refers to: complementarity to other tourism resources, as well as the differentiation from other nearby cultural assets, while differences among other sub-indicators are insignificant. On the other hand, the difference in assessment of sub-indicators in the sector of management of cultural asset is almost non-existent. An average grade for this group of sub-indicators by tourists is 41.5 while author's grade is 42 . In this case too, the opinion of authors and tourists coincides in a great extent. It leads to the conclusion that Mileševa monastery is characterized by high value of robustness. Within this group of sub-indicators, the most noticeable deviation in the evaluation of tourists and 
authors refers to the existence of a cultural asset management plan. Tourists have estimated this sub-indicator with average grade 1.7. However, a cultural asset management plan does not exist, and there is no information that is currently being prepared, so a realistic score for this subindicator is 0 .

From the above mentioned it can be concluded that the results of the assessment of authors and tourists largely coincide, so they may be considered as relevant for assessing the benefits of cultural asset for tourism development.

\title{
References:
}

1. Berić, D., Ivkov-Džigurski, A., Tomić, N. (2012): Tourist valorization of Roman imperial city Felix Romuliana. Bulletin of the Serbian Geographical Society, Serbian Geographical Society, Belgrade, Vol. 92, 2.

2. Besermenji, S., Pivac, T. (2008): Tourist importance of Sirmium. Proceedings of the Faculty of Geography, Belgrade, no. 56, p. 151-164.

3. Besermenji, S., Marković, S., Jovičić, D. (2010): Tourist valorization of the religious buildings built in the style of Raška school. Proceedings of the Faculty of Geography, Belgrade, no. 58, p. 93-110.

4. Drobnjaković, M. (2012): Prijepolje - a factor of regional integration of Southwestern Serbia. Geographic Instutute "Jovan Cvijić", Serbian Academy of Sciences and Arts, Belgrade.

5. Dulić, G. (2001): Medieval architecture, History of architecture. Institute for textbooks and teaching aids, Belgrade. Belgrade.

6. Janković, Ž. Ž. (2007): Serbia - travel guide-atlas through space and time. Intersistem,

7. Mandić, S. (2012): Mileševa monastery. Management of the Mileševa monastery, Prijepolje.

8. Plavša, J., Ratković, S. (2007): Tourist potentials and rural tourism of Prijepolje municipality. Proceedings of the Department of Geography, Tourism and Hotel Management, Novi Sad, no. 36, p. 85-99.

9. Stanković, S. (2004): Tourist valorization of geomorphological objects of the geoheritage of Serbia. Bulletin of the Serbian Geographical Society, Serbian Geographical Society, no. 84, vol. 1, p. 79-88, Belgrade.

10. Tomić, N. (2011): The Potential of Lazar Canyon (Serbia) as a Geotourism Destination: Inventory and Evaluation. Geographica Pannonica, Vol.13, Issue 2, pp.103-112.

11. Tomka, D. (1998): Culture through space, time and tourism. Institute of Geography, Faculty of Science, University of Novi Sad, Novi Sad, pp. 245-281.

12. Hadžić, O. (2005): Cultural tourism. Department of Geography, Tourism and Hotel Management, Faculty of Science, University of Novi Sad, Novi Sad.

13. Cros, du H. (2000): Planning for Sustainable Cultural Heritage Tourism in Hong Kong,

FinalReport to the Lord Wilson Heritage Trust Council, SAR.

14.Data obtained from curator of the monastery.

УДК 33

\section{Туристическая валоризация монастыря Милешева (Сербия)}

\author{
1 Джавана Босков \\ ${ }^{1}$ Стефан Котрла \\ ${ }^{2}$ Кристина Косик \\ 1 Дайна Лулик
}

\footnotetext{
1 Университет Нови-Сад, Сербия

Факультет естественных наук, Кафедра географии, туризма и гостиничного менеджмента

E-mail: boskovjovana@gmail.com

2 Доцент
} 
Аннотация. Монастырь находится в долине реки Милешевка, т.е. в месте, где река Косаничка впадает в реку Милешевка. Это в шести километрах от города Приеполе и представляет столицу собой епархии Милешева. Монастырь построен в стиле рашской школы и датирован 1219-1235 годами. Монастырю Милешева придается большое значение в культуре, искусстве и истории сербского народа. Он также играет важную роль в туризме Приеполе и представляет собой культурное достояние. В этой работе авторы хотели представить туристическую валоризацию монастыря Милешева. Основная цель данной работы - рассмотреть различные ценности культурного достояния, используя Хиллари дю Кро модель туристической валоризации.

Ключевые слова: туристическая валоризация, Хиллари дю Кро модель, монастырь Милешева, Приеполе, Сербия. 